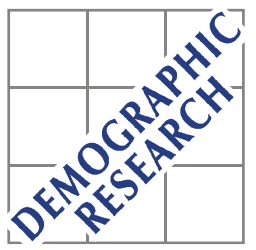

Demographic Research a free, expedited, online journal

of peer-reviewed research and commentary in the population sciences published by the Max Planck Institute for Demographic Research

Konrad-Zuse Str. 1, D-18057 Rostock · GERMANY

www.demographic-research.org

DEMOGRAPHIC RESEARCH

VOLUME 23, ARTICLE 24, PAGES 669-696

PUBLISHED 01 OCTOBER 2010

http://www.demographic-research.org/Volumes/Vol23/24/

DOI: $10.4054 /$ DemRes.2010.23.24

Research Article

\title{
Studying historical occupational careers with multilevel growth models
}

\section{Wiebke Schulz}

\section{Ineke Maas}

This publication is part of the proposed Special Collection "Social Mobility and Demographic Behaviour: A Long-Term Perspective", organized by Guest Editors Cameron Campbell, Jan Van Bavel, and Martin Dribe.

(C) 2010 Wiebke Schulz \& Ineke Maas.

This open-access work is published under the terms of the Creative Commons Attribution NonCommercial License 2.0 Germany, which permits use, reproduction \& distribution in any medium for non-commercial purposes, provided the original author(s) and source are given credit.

See http:// creativecommons.org/licenses/by-nc/2.0/de/ 


\section{Table of Contents}

$\begin{array}{lll}1 & \text { Introduction } & 670\end{array}$

$2 \quad$ Historical data and growth models 671

3 By way of example - hypotheses on the effects of experience, $\quad 674$ father's occupational status and marital status on career success

$\begin{array}{lll}4 & \text { Data, variables, and method } & 678\end{array}$

$\begin{array}{lll}4.2 & \text { Data \& context } & 678 \\ 4.3 & \text { Dependent variable } & 681\end{array}$

$\begin{array}{lll}4.3 & \text { Independent variables } & 682\end{array}$

4.4 Control variables $\quad 682$

4.5 Models 684

4.5 Descriptive results 684

4.6 Test of the hypotheses 686

$5 \quad$ Discussion and conclusion $\quad 691$

$\begin{array}{ll}\text { References } & 693\end{array}$ 


\title{
Studying historical occupational careers with multilevel growth models
}

\author{
Wiebke Schulz ${ }^{1}$ \\ Ineke Maas $^{2}$
}

\begin{abstract}
In this article we propose to study occupational careers with historical data by using multilevel growth models. Historical career data are often characterized by a lack of information on the timing of occupational changes and by different numbers of observations of occupations per individual. Growth models can handle these specificities, whereas standard methods, such as event history analyses cannot. We illustrate the use of growth models by studying career success of men and women, using data from the Historical Sample of the Netherlands. The results show that the method is applicable to male careers, but causes trouble when analyzing female careers.
\end{abstract}

\footnotetext{
${ }^{1}$ Utrecht University, Department of Sociology/ICS, Heidelberglaan 2, 3584 CS Utrecht, The Netherlands. E-mail: w.schulz@uu.nl. This project is funded by The Netherlands Organisation for Scientific Research (NWO), Grant \# 400-08-230.

${ }^{2}$ Utrecht University, Department of Sociology/ICS, Heidelberglaan 2, 3584 CS Utrecht, The Netherlands. E-mail: i.maas@uu.nl.
} 


\section{Introduction}

Recently there has been a renewed interest in the study of the historical career (see Mitch, Brown, and van Leeuwen 2004 for an overview). Economists, demographers and sociologist likewise have been motivated by recent developments in data collection, e.g., the digitalization of censuses and population registers, providing them with new but complex historical data on occupational careers. The new data enable the study of old as well as new research questions. Examples of questions which were raised include: whether careers become more successful over time, and whether the influence of individual characteristics such as schooling on individual careers varied over historical time (Mitch, Brown, and van Leeuwen 2004).

The new data not only present new possibilities, but also new challenges. They usually lack information on the exact timing of changes in occupational status and individuals differ with respect to the amount of information on occupational status that is available. This makes the most common method to study careers, i.e., event history modeling, less applicable.

The goal of this paper is to propose and employ a new method for studying occupational careers using historical data. More specifically the method is appropriate for studying career success. By career we mean any kind of working life history, thus any succession of occupations of an individual. Successful careers are characterized by two dimensions. First, careers are more successful if they start at a higher level of occupational status.Second, the occupational status of individuals having successful careers increases faster over the life course.

To illustrate our method we will use the Historical Sample of the Netherlands (HSN 2008). These are excellent data to study occupational careers of individuals: the data comprise information on occupational careers of almost 2000 men and women born between 1850 and 1882. At the same time these data show the two characteristics challenging common methods of studying careers. Individuals have at least one occupational measurement, at most twenty, and on average four. The exact timing of a change in the occupational status is not known. Instead occupations are noted down at the time of vital events such as marriage and the birth of a child.

We propose to use growth models to study careers. The main idea behind these models is that occupational status increases with experience in the labor market. Moreover, the models allow studying the impact of time constant predictors (e.g., father's occupational status) and time varying predictors (e.g., marital status). Both types of predictors can influence the starting point of the career and the speed of growth.

The structure of this paper is as follows. First, we provide a brief discussion of common issues of historical data which make more standard methods less applicable. 
Subsequently, we will propose our method to study careers with historical data. We then formulate some hypotheses which are tested with the Historical Sample of Netherlands. The data in use will be described and the hypotheses will be tested. We conclude with a discussion of the proposed method and an outlook for further research.

\section{Historical data and growth models}

The most common types of sources of historical data on occupational careers are continuous registers, kept by the church or by the state, and linked censuses, as well as sometimes a combination of multiple sources (Reher and Schofield 1993). Using historical data to study occupational careers has clear advantages. They offer insights for the historian of careers as well as for the sociologist who studies long-term developments in stratification because they often cover a substantial period in people's lives and a long period of historical time. Moreover, the data include information on the occurrence of vital events, for instance the date of marriage and of the birth of children, which are often considered to be important independent variables. Nonetheless, historical data on careers have also at least two disadvantages.

The first disadvantage is that the exact start and end date of an occupation is not known. Continuous registers such as population registers provide information about an individual's occupation at a certain date (e.g., at the birth of a child, or at the move to another address), however when someone started to have a certain occupation is not known. Linked census data present the same challenge. However, since censuses are held regularly individual's occupations are measured on a more regular basis than in population registers.

Second, data based on continuous registers record occupations at the time of vital events, therefore individuals have differential numbers of occupational recordings, depending on the number of vital events. Moreover, depending on when in a person's life vital events occur occupations are registered at different ages.

Given these two drawbacks of historical data a widely used method in contemporary career research, i.e., event history modeling, in which the exact timing of career moves is studied, is not suitable (see Maas 2004 for a review of the use of eventhistory-analysis in career research).

To make use of the advantageous characteristics of historical career data we propose to use multilevel growth models (Hox 2002; Raudenbush and Bryk 2002). In multilevel growth models two levels are distinguished. The first is the individual level. At the second level several measurements per individual for an individual outcome variable are included. The scores of the individual on the outcome variable are assumed to change over time. In the case of career research this outcome is occupational status. 
The change over time is modeled with a so-called growth curve (Figure 1). Each individual can have his or her own 'growth' of status over time. Growth curves can differ with respect to their starting point (i.e., a random intercept, compare Figure 2) or with respect to their growth (i.e., a random slope, compare Figure 3).

In growth models, differences between individuals can be modeled using time invariant and time variant characteristics. Time invariant characteristics, such as occupational status of the father or gender, may cause the growth curve to start on a higher or lower level and/or to grow at a different speed. The same is true for time variant characteristics, such as marital status. However, time variant characteristics do not cause the growth curve to start at a higher level, but they cause it to jump to a higher (or lower) level at the point in time where this characteristic changes. From that time point onwards, they may also change the speed of growth (Figure 4).

\section{Figure 1: Example of a growth curve of occupational status over time}

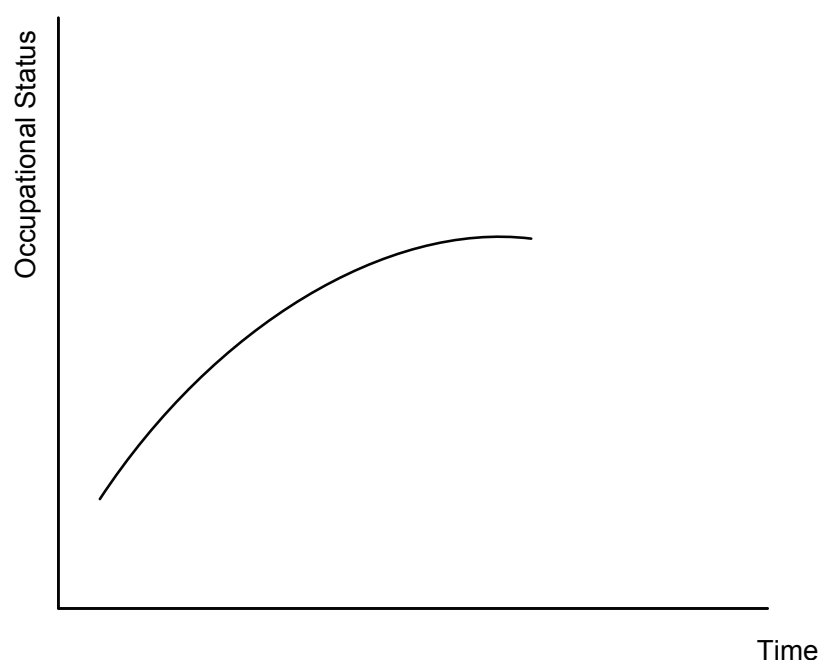


Figure 2 Example of two growth curves with different starting points (i.e., intercept)

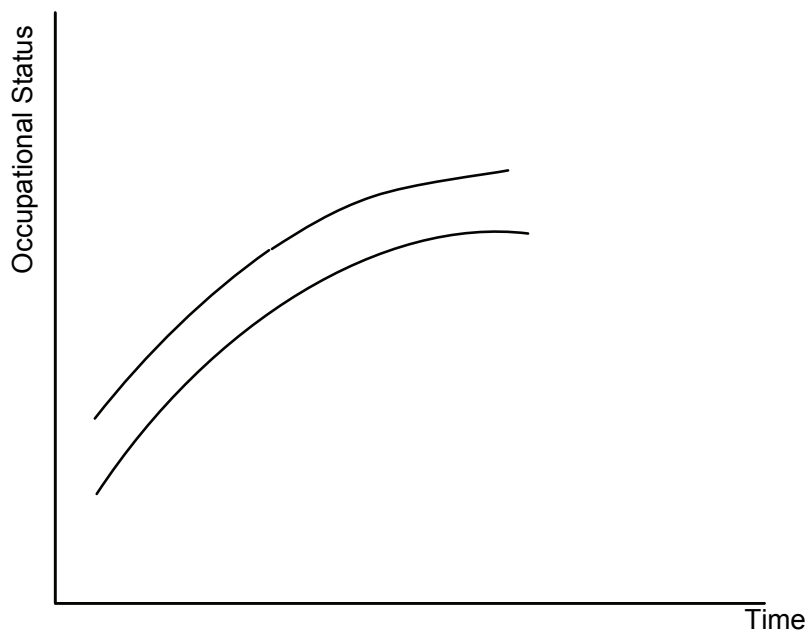

Figure 3: Example of two growth curves with different speed of growth (i.e., slopes)

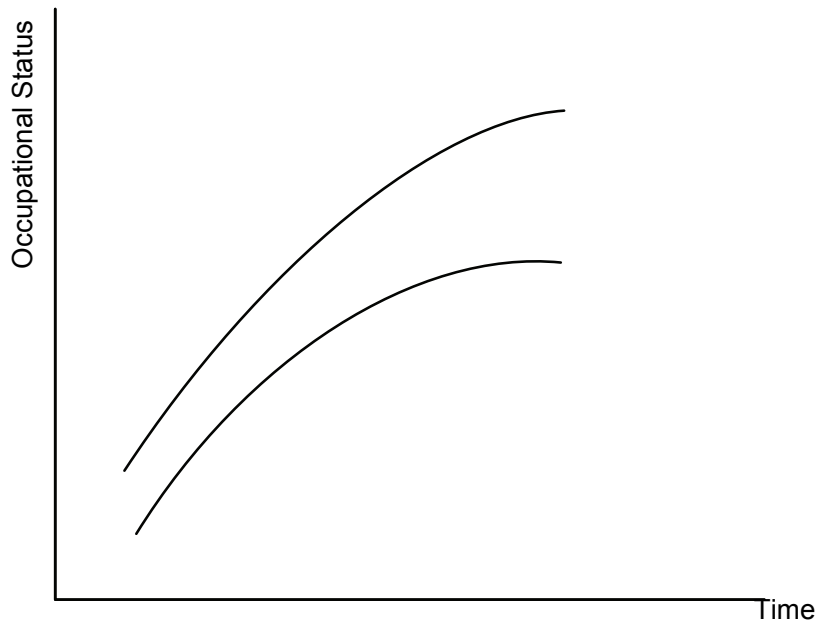


Figure 4: Example of the effect of a time varying characteristics, i.e., marriage, on both the level of the growth curve and the speed of growth

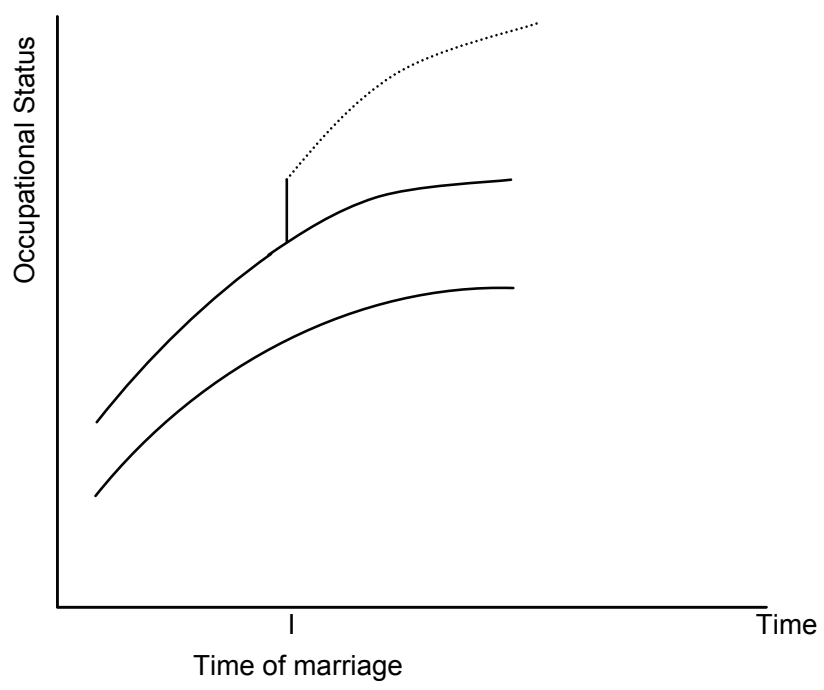

Although there is to our knowledge no application of growth modeling in career research, growth models are widely used in psychology, educational sciences and economics. These models are for instance used to study growth in learning, e.g., intelligence growth or free recall of pupils over a period of time (Sagiv 1979). Another example is the longitudinal assessment of growth in teacher's effectiveness in different school classes. Multilevel growth models have been used to study the evaluation of almost 200 teachers over 13 years in around 6,000 classes (Marsh 2007). Moreover, in economic research multilevel growth models have been used to model income growth over a life course (Pavan 2006).

\section{By way of example - hypotheses on the effects of experience, father's occupational status and marital status on career success}

The most basic approach which relates individual characteristics to career success is formulated in the human capital theory. Human capital refers to formal as well as informal education and to work experience, general or specific with regard to one's 
occupation (Mincer and Polachek 1974). It has been argued that those with more human capital are more likely to get ahead (Becker 1975). Over a life course individuals gain experience specifically with regard to their tasks or in general with regard to their occupation. Work experience makes employees more productive and signals to the employer that less training costs are needed in comparison to a worker with less experience. Experienced workers are more likely to be successful, and they are also the last people to be fired because they are the most valuable to an employer (Mincer and Polachek 1974). Because the additional experiences an employee can gain are finite, we expect that the growth of status slows down with increasing age. This expected relation between experience and occupational status lies at the heart of the growth model because it describes the basic pattern of growth of status over the life course (compare Figure 1). H1: Occupational status increases with experience, but to a lesser extent at older ages.

Second, how successful a career starts is, for example, affected by time constant characteristics, e.g., father's occupational status ${ }^{3}$. Especially in pre-industrial and industrializing societies the occupational status of the father is considered to be one of the most important resources (Blau and Duncan 1967; Ganzeboom, Treiman, and Ultee 1991; Kaelbe 1985; Kerr et al. 1960; Maas and van Leeuwen 2002; Zijdeman 2008). Fathers with a higher occupational status could help their children to attain occupational training or some education in order to enter their occupational career at a high level. If children followed their parent's occupation the parents could provide training to the children, and the children might inherit a family run shop, company, farm, or financial capital (Treiman 1970). By influencing the starting position of the child parents provided a base for future success (Kerckhoff 1995; Shavit and Blossfeld 1993). H2: The higher the occupational status of the parents the higher the occupational status at which the children start their career.

We expect that parents not only gave their children an initial advantage in the labor market, but also influenced the pace at which their careers progressed. During the occupational career parents could influence the success of their children by providing work related advice, e.g., information concerning certain occupations or job opportunities, or introducing children to their work related contacts. Therefore, we expect that the speed with which careers of children from high status parents advanced was faster compared to children from lower status parents. H3: The higher the occupational status of parents the faster the speed at which the occupational status of their children grows.

\footnotetext{
3 Although not invariant in the strict sense of the word, father's occupational status is often treated as invariant because of a lack of dynamic information, and because at the marriage of their children, fathers have often reached a stage in their occupational career where changes in status are less common (compare figure 1).
} 
While the influence of father's status on children's occupational status is rather well supported by empirical research (see Ganzeboom, Treiman, and Ultee 1991 for a review) there is no conclusive evidence on how this relation changed over time, i.e., in the time before the Second World War (e.g., Kaelble 1985). Some advocate that the influence of the father remained the same in industrializing societies (Erikson and Goldthorpe 1992); others argue that there is a steady decline of the effect of father's status on that of his children (Ganzeboom, Luijkx, and Treiman 1989).

According to theory, however, the influence of the father on his children's social background became less important in the course of industrialization. The Logic of Industrialism thesis (Kerr et al. 1960; Treiman 1970) states that modernization processes (e.g., mechanization of work, urbanization) led to an increase in the gross intergenerational mobility by influencing the determinants of occupational mobility. A number of related mechanisms have been proposed which restricted parents in their possibilities to have a direct influence on the occupational decisions of their offspring (see Treiman 1970). First, due to modernization and industrialization processes a diversification of jobs and occupations took place. As a consequence, the skills of the parents were often no longer useful for their children. Second, in the course of industrialization employers are assumed to be forced to choose their employees increasingly on the basis of their merits, rather than on the basis of their social background (Blau and Duncan 1967; Kerr et al. 1960). The occupational structure became more diversified, new occupations emerged, and in order to get the best skilled and qualified workers, employers had to focus more on anindividual's achievement rather than on an individual's social background (Blau and Duncan 1967:430). Third, due to the specialization of labor, a greater number of jobs required specialized and longer training which families could not provide. In sum, we expect that the occupational status of fathers became less important for the success of the career of the children over time. H4: Over time the occupational status of parents is having a smaller influence on the starting level of the occupational status of their children. Note that we study over time changes only for the influence of parent's status on the starting point of the career of children. For now we do not consider any over time changes of the effect of parent's status on the speed of growth of occupational status.

Next to time constant characteristics like social background also time varying characteristics influence individual's careers. As an example for a time varying predictor we study the effect of being married on occupational status. We come to different expectations for being married for the careers of men and women.

According to the male breadwinner role model an increase in occupational success is to be expected for men after marriage, for two reasons. First, once men get married and have children they get a greater responsibility and society expects them to function as the (often only) family provider. Due to the increased responsibility men are assumed 
to invest more time and effort in their work and therefore become more productive (Horrell and Humphries 1995; Kalmijn and Luijkx 2005; Lewis 2001).

Second, employers would positively discriminate in favor of married men: married men are favored by employers since they are believed to be more committed to their jobs. Employers are also less prone to fire married men as this is considered less fair then firing men with fewer responsibilities. On the grounds of these ideas married men can be expected to have more successful careers than nonmarried men (Korenman and Neumark 1991).

The housewife role model predicts that for women, marriage had the opposite effect. In Dutch society around the end of the $19^{\text {th }}$ century it was highly respectable for women to only focus on the household and childrearing. However, because lower class families could financially not afford to follow this example, women from these classes did not drop out of the labor market entirely. Instead, they concentrated their activities in cottage industries, family farm labor, serving and personal services. Thus working in areas in which informal, less organized, and less successful careers took place (Leydesdorff 1977; van Poppel, van Dalen, and Walhout 2009).

Besides self-selection into less successful careers, women also faced considerable restrictions implemented by employers, e.g., to ascend certain job ladders. They were more often assigned to dead-end positions (Goldin 1994) or so called "marriage-bars" kept women from being employed once they got married (Leydesdorff 1977; Thurow 1975). In the Netherlands occupational restrictions towards married women were abandoned only after the 1920s. Because of social expectations and labor market discrimination we expect married women to have less successful careers than women who did not marry (yet).

H5a: After men get married their occupational status is higher than before marriage. H5b: After women get married their occupational status is lower than before marriage.

Hypothesis 5a assumes that at marriage the occupational status of men jumps to a higher level, and subsequently develops parallel to the careers of (still) unmarried men. This seems to be an unrealistic assumption. Societal expectations towards married people probably not only influence the career at the time of marriage but also every further occupational decision that is to be taken. For instance, the motivating effect of the responsibility as a family breadwinner will hold also for the time after marriage. We therefore expect that men who are married will not only progress in their career at a higher level, but that their career will also grow faster (compare figure 4). Likewise, women who are expected to get married or have gotten married will face societal expectations or discrimination also later in their occupational career. Thus, we also expect the impeding effect of being married for female occupational status to affect every occupational decision after marriage, i.e., to decrease the speed at which their 
status grows. H6a: For men after marriage the speed at which the occupational status grows is faster than before marriage. H6b: For women after marriage the speed at which the occupational status grows is slower than before marriage.

The influence of marital status on occupational success is, like the effect of father's occupational status, assumed to change over time. Often a three-stage historical development of the economic integration of women is assumed. In premodern societies an extensive integration of female labor into the household economy is assumed, in industrial societies it came to a wide exclusion of women from official work and during the later stages of modernization women were re-integrated into paid work (for a discussion and critique of this model see: Pfau-Effinger 2004). The Netherlands to some extent present a special case as already before a transition to industrialization the male bread winner model and the accompanying female housewife model were important family models (Pfau-Effinger 2004:385). Until the 1950s these models became even more deeply rooted in Dutch society. As shown by van Poppel, van Dalen, and Walhout (2009) for example, from the 1820s onwards increasingly fewer Dutch women registered their occupations in official documents such as marriage certificates. We therefore expect H7a: Over time men increasingly had a higher occupational status after marriage than before marriage. H7b: Over time women increasingly had a lower occupational status after marriage than before marriage. Note that we study over time changes only concerning the influence of getting married on the status level of the occupational career. We do not consider any over time changes of the effect of being married on the speed of growth.

\section{Data, variables, and method}

\subsection{Data \& context}

The Historical Sample of the Netherlands (HSN) provides us with information on occupational careers of individuals representative of the Dutch population of the nineteenth and twentieth centuries. The HSN is an excellent database to study careers of men and women in different regions, and over time.

The HSN starts from a sample of birth registers from the period 1812-1922 $(\mathrm{n}=78,000)$. The main data sources for individual life histories are birth certificates, death certificates, marriage certificates, and the population registers, which were introduced to obtain a continuous registration of the composition of households and the place of residence of each individual in the Netherlands. Every time a vital event occurred (e.g., marriage, birth of a child, move to another municipality) information on the individual, including the occupation, and if applicable of his/her family was 
recorded and updated respectively. That means that the amount of occupational information we have about an individual is dependent on the number of vital events such as moving and birth of a child, and not on the occupational career itself (e.g., number of different occupations).

The collection of the data is still underway, therefore we will use a subsample of the data (HSN release life courses 2008_01) which consists of life courses of individuals born between 1850 and 1922 in the provinces of Friesland, Zeeland, Utrecht and the city of Rotterdam (see Mandemakers 2004). Zeeland and Friesland are two predominantly rural provinces; the province of Utrecht was partly urban and partly rural. In comparison to other European countries the Netherlands underwent the processes of industrialization late, i.e., during the late $19^{\text {th }}$ and early $20^{\text {th }}$ century. The time period the data stem from - from 1865 onwards - is therefore especially interesting because it was characterized by a rapid transformation of the labor market. New modes of production led to the development of large production units (Van Zanden and van Riel 2000) and an increasing number of new occupations (van Leeuwen and Maas 2007). Likewise agricultural production underwent mechanization processes.

The data comprise information on the respondents' date of birth, marital status, literacy, father's occupation, all migrations, as well as occupations of the respondents. Because we aim at studying occupational careers we restricted the sample to the ages in which most people belonged to the working population, i.e., people who are at least 15 years old without any maximum age. We study the period 1865-1940. In 1940 a change in the population registers made them less useful for studying occupational careers. With the introduction of the personal family card (persoonsgezinskaart) in 1940 the date of registration of occupational information is no longer known. Most of the birth cohorts in our study more or less finished their active occupational life by 1940 . Complete information, i.e., information on at least one occupation and information on all independent variables is available for 5,544 occupations of 1,406 men and 2,431 occupations of 824 women.

Figure 5 presents the 'occupational information rate' by age for men and women. This ratio is calculated by dividing the number of observations of an occupation by the number of respondents per year of age (Maas and van Leeuwen 2004). For both men and women, around the age of marriage there is a peak in the occupational information (ca. age 16-27), for women this peak begins earlier than for men. After the age of marriage there is a gradual decrease in occupational information. For women the decrease is somewhat steeper than for men, so that after the age of around 24 there is always more occupational information for men than for women. 


\section{Figure 5: Occupational information rate by age}

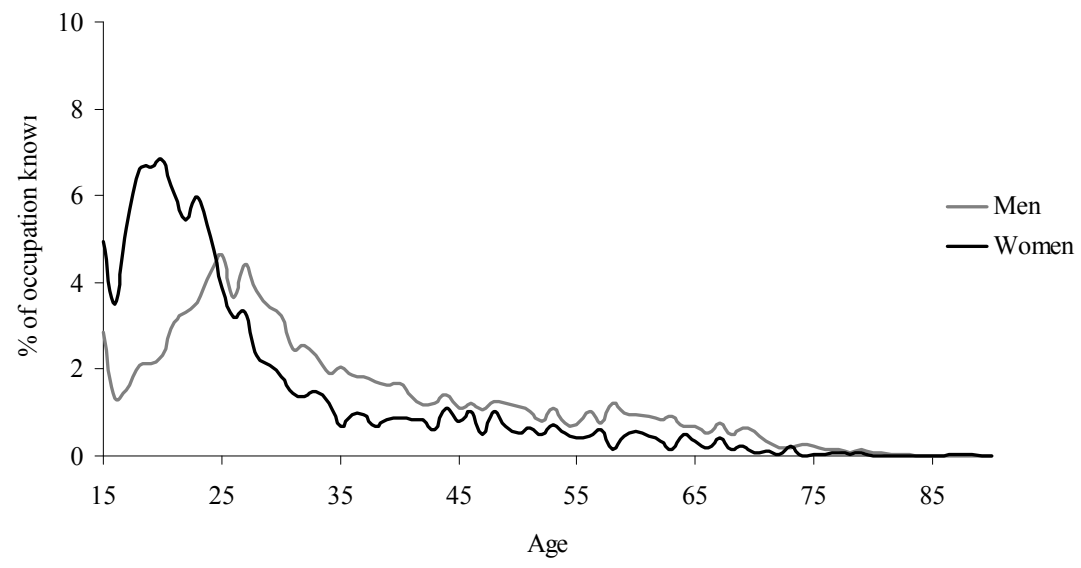

Some critics of this type of data argue that the information on occupations of women is less complete than that on occupations of men, because the head of the household would not always provide information about the occupations of the female household members. This may indeed be the case, but it is difficult to verify, since the lack of information on occupations of women may also indicate their lower labor force participation. Furthermore, the less extensive information on the careers of women may be a result of the fact that men, and not women, registered new born children with the municipality. In any case, information on female occupational careers is not in general lacking in the data. In the HSN there is extensive information on the careers of a large number of women, especially before marriage. In the discussion we will come back to this, when interpreting our results.

Studies of social mobility in preindustrial or industrializing societies are also challenged when the society is dominated by one very large occupational group, usually farmers. For the period and sample under study this problem does not occur. During this period in the Netherlands the agricultural sector had the highest decrease in terms of employment rates (Van Zanden and Van Riel 2000:352). As a consequence only 9\% of all occupational observations in the sample are farming occupations. Furthermore, the occupational titles allow distinguishing between different occupations within the farming sector and these occupations in turn have different positions on the status scale that we use. For instance individuals who owned a farm have a status of 60.9 , whereas 
farm laborers have a status of 32.1. There are a number of other occupations such as workers in a tree nursery (58.0), pastorals (48.4) and milkers (42.9).

\subsection{Dependent variable}

Occupational Status: Assigning social positions to individuals is a difficult task in itself. Doing so over two centuries and across different regions (national or international) is even more so. Differing occupational terminology hindered international and over time comparisons of occupational status for a long time (Van Leeuwen, Maas, and Miles 2004). Such comparisons became possible after the development of the Historical International Standard Classification of Occupations (HISCO) (Van Leeuwen, Maas, and Miles 2004), based on the International Standard Classification of Occupations 1968 of the International Labour Office (ISCO68 1969). All occupational information we use has been classified in HISCO. This enables the use of the recently developed historical status scale HISCAM, which assigns status to all HISCO categories (Lambert et al. 2008). For the development of the HISCAM scale the same scale estimation techniques were used as for the contemporary versions; the socalled CAMSIS scales (Cambridge Social Interaction and Stratification) (Prandy 2000). These scales are built on the assumption that patterns of social interaction between people from different occupational strata are representative of the overall occupational stratification structure (Bottero 2005; Prandy and Lambert 2003). This means that the main general determinant of patterns of social interaction between people with certain occupations is the hierarchical position of these occupations in society (factory workers are not likely to interact with lawyers). In the case of HISCAM information on intergenerational mobility from 1.5 million marriage records from six different countries (Britain, Canada, France, Germany, the Netherlands, and Sweden) covering the period 1800-1938 was used to estimate the social distances between occupations. ${ }^{4}$ If intergenerational mobility between two occupations was relatively common, the estimated distance between these occupations on the HISCAM scale is small. If mobility is rare, the estimated distance is large. The main - hierarchical - dimension behind the estimated distances between all pairs of occupations, was transformed into a scale ranging from 1 to 99 , where a higher value indicates a higher occupational status. A servant for example has a HISCAM-score of 10.6, a lawyer a score of 99.0 and a tailor takes a middle position with a score of 49.7 .

\footnotetext{
${ }^{4}$ Using Goodman's scaled association models (Goodman 1979).
} 


\subsection{Independent variables}

Experience: Occupational experience will be indicated by the age of the respondent. We study the occupational career from the age of 15 onwards, thus 15 was subtracted from the age of the respondent. Moreover, age was divided by ten. Every time information has been updated in the original sources (e.g., marriage or death certificates) also the age of the respondent has been noted. A quadratic term of age was added to the analyses in order to test the hypothesis that the effect of experience declines over the occupational career. Note that age is a better indicator for men's occupational experience than for women's, as female careers are more likely to be interrupted by giving birth and taking care of children.

Father's occupational status: Like respondent's occupation also the occupations of the fathers have been coded into HISCO and then given a HISCAM-score. If more than one occupation of the father is known the occupational information about the father which is closest to the respondent's birth was chosen.

Marital status: Through information from wedding certificates we reconstructed who married when. Being married is treated as a time variant characteristic. To all points in time before marriage at which an occupation is observed the value 0 was assigned, and to all points in time after marriage a 1.

Year: the variable year measures the number of years since 1865 and was divided by 10 . Moreover, in the interaction term year was centered adjusting the null point to the year 1900 .

\subsection{Control variables}

Marriage certificate: Marriage certificates are one of the typical sources used by the HSN. Critics argue that occupational measurements at marriage fluctuate upwards because it is a key social event in an individual's life. To control for this we created a variable that is 1 for all occupational information from a marriage certificate and 0 otherwise.

Incomplete: Not all of the life courses included in the HSN are complete yet. To control for possible biases of incomplete life courses we include this information in the analyses. The variable incomplete indicates whether part of the register information is still missing (1) or whether all information is complete (0). Incomplete life courses do not necessarily mean that occupational information is missing. It could also be a missing death certificate which makes the information not (yet) complete.

Descriptive information on all variables is provided in Tables $1 \& 2$. 
Table 1: Descriptives of time invariant and time varying variables, male respondents

\begin{tabular}{lcccc}
\hline Time invariant variables (N=1406) & Min & Max & Mean/\% & S.d. \\
Father's occupational status (HISCAM) & 10.6 & 99.0 & 45.9 & 12.8 \\
Time varying variables (N=5544) & & & & \\
\hline Occupational status (HISCAM) & 10.6 & 99.0 & 47.3 & 15.8 \\
Experience/10 & 0.0 & 7.5 & 2.0 & 1.5 \\
(Experience/10) & 0.0 & 56.3 & 6.4 & 8.4 \\
Married & 0 & 1 & 55 & 17.1 \\
Year/10 & 0.0 & 75.0 & 36.8 & \\
Control variables & & & & \\
\hline Incomplete & 0 & 1 & 32 & \\
Marriage certificate & 0 & 1 & 13 & \\
\hline
\end{tabular}

Note: Experience starts to count at age 15, Year starts to count at 1865.

Table 2: Descriptives of time invariant and time varying variables, female respondents

\begin{tabular}{lcccc}
\hline Time invariant variables (N=824) & Min & Max & Mean/\% & S.d. \\
Father's occupational status (HISCAM) & 32.1 & 99.0 & 45.4 & 12.6 \\
Time varying variables (N=2431) & & & & \\
\hline Occupational status (HISCAM) & 10.6 & 98.4 & 23.6 & 20.1 \\
Experience/10 & 0.0 & 7.2 & 1.3 & 1.3 \\
(Experience/10) & 0.0 & 51.9 & 3.4 & 6.3 \\
Married & 0 & 1 & 17 & 15.0 \\
Year/10 & 0.0 & 75.0 & 26.2 & \\
Control variables & & & & \\
\hline Incomplete & 0 & 1 & 30 & \\
Marriage certificate & 0 & 1 & 4 & \\
\hline
\end{tabular}

Note: Experience starts to count at age 15, Year starts to count at 1865. 


\subsection{Models}

The following sequence of models is estimated both for men and women. The null model informs about the variation in occupational status between individuals and within individuals. The first model tests the basic idea of growing career success by experience. It includes the predictors for working experience, working experience squared and year of measurement.

The second model additionally includes the time constant characteristic father's occupational status. Interactions of father's occupational status with experience and year are added in model 3.

In model 4 the time varying variable being married is included. The fifth and last model includes the interaction of being married with experience and with year. We thus test whether marital status changes the speed at which career success grows over an individual's life course and whether the effect of marriage on the level of occupational status changes over historical time.

In all models an indication of whether the source information for an individual is complete is included. Models 4 and 5 which include the main effects of being married also include the control variable indicating whether information stems from the marriage certificate.

\subsection{Descriptive results}

The three careers shown in figure 6 exemplify how diverse the careers recorded in the HSN database are. The careers differ in length of the observation period, number of observations, as well as complexity. The careers shown in Figure 6 range from a career which starts and continues without any change in occupational status in the lower part of the status scale ("worker") to a career which clearly shows upward mobility ("teacher"). The teacher had a successful career as he started as a school teacher and his last occupation is head of a school. The worker on the contrary remains in the same occupation during the period of his life that we observe. The career of the "gardener" displays most fluctuation in occupational status: he started as a coachman, became a servant and worked again as coachman. After a period in which he worked as a gardener, he finished his career as a tree grower and finally as a tree grower assistant. 


\section{Figure 6: Three careers from the HSN data; time points of measurement of occupational status are indicated by dots}

Three Careers

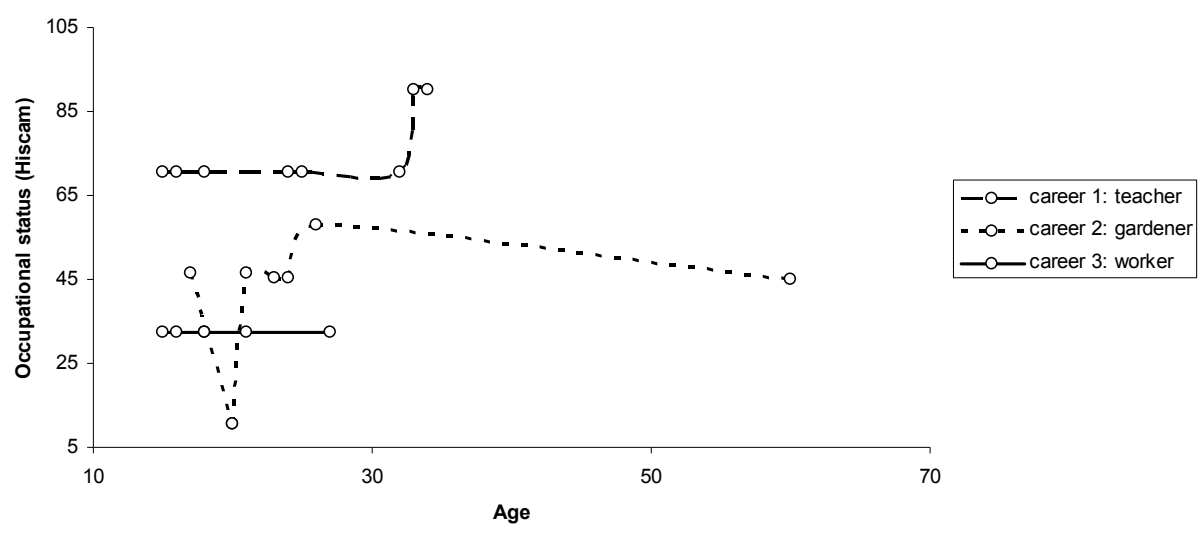

Tables 3 and 4 present characteristics of career trajectories of men and women by marital status. Men who ever married have on average longer observation periods, namely 24 years in comparison to 18 years for men who never married, but the variance in both groups is very large. Never and ever married men also differ in the average number of occupational measurements, respectively 3 and 4 , which is probably due the fact that the first group lacks information at marriage. The mean age at first occupational measurement is the same for both groups of men, namely 23 years.

Women have on average the same number of occupational measurements as never married men. However, their occupational trajectories are on average only 9.4 years long and thus much shorter than those of men. Never married women have somewhat longer careers than women who marry (12 years compared to 8 years). The mean age at the first occupational measurement is similar for men and women, but women end their occupational career much earlier than men, on average around age 32, although we do observe some occupations for women at age 64 . This means two things for the analyses. The first consequence is that our estimation of the growth of the careers of women is much better for the first half of their career than for the second half, because there are much fewer observations that pertain to this second half. Secondly, since especially married women left the labor market the estimation of the second half of women's careers is based on a selective group of mainly never married women. We return to this issue in the discussion. 
Table 3: Some descriptive characteristics of the occupational careers of men in the HSN-data by marital status

\begin{tabular}{lcccccccc}
\hline $\begin{array}{l}\text { Individual } \\
\text { characteristic }\end{array}$ & $\mathrm{N}$ & $\begin{array}{c}\text { Minimum } \\
\text { length in } \\
\text { years }\end{array}$ & $\begin{array}{c}\text { Maximum } \\
\text { length in } \\
\text { years }\end{array}$ & $\begin{array}{c}\text { Mean } \\
\text { length in } \\
\text { years }\end{array}$ & $\begin{array}{c}\text { S.d. } \\
\text { length in } \\
\text { years }\end{array}$ & $\begin{array}{c}\text { Mean \# } \\
\text { occupations }\end{array}$ & $\begin{array}{c}\text { Mean age } \\
\text { at first } \\
\text { occupation }\end{array}$ & $\begin{array}{c}\text { Mean age } \\
\text { at last } \\
\text { occupation }\end{array}$ \\
\hline $\begin{array}{l}\text { All male } \\
\text { respondents }\end{array}$ & 1407 & 0 & 64 & 22.5 & 18.1 & 3.9 & 23.5 & 46.1 \\
$\begin{array}{l}\text { Married } \\
\begin{array}{l}\text { Never } \\
\text { married }\end{array}\end{array}$ & 997 & 0 & 64 & 24.3 & 18.1 & 4.2 & 23.6 & 47.9 \\
\hline
\end{tabular}

Table 4: $\quad$ Some descriptive characteristics of the occupational careers of women in the HSN-data by marital status

\begin{tabular}{lcccccccc}
\hline $\begin{array}{l}\text { Individual } \\
\text { characteristic }\end{array}$ & $\mathrm{N}$ & $\begin{array}{c}\text { Minimum } \\
\text { length in } \\
\text { years }\end{array}$ & $\begin{array}{c}\text { Maximum } \\
\text { length in } \\
\text { years }\end{array}$ & $\begin{array}{c}\text { Mean } \\
\text { length in } \\
\text { years }\end{array}$ & $\begin{array}{c}\text { S.d. } \\
\text { length in } \\
\text { years }\end{array}$ & $\begin{array}{c}\text { Mean \# } \\
\text { occupations }\end{array}$ & $\begin{array}{c}\text { Mean age } \\
\text { at first } \\
\text { occupation }\end{array}$ & $\begin{array}{c}\text { Mean age } \\
\text { at last } \\
\text { occupation }\end{array}$ \\
\hline $\begin{array}{l}\text { All female } \\
\text { respondents }\end{array}$ & 824 & 0 & 64 & 9.4 & 13.0 & 2.9 & 22.0 & 31.5 \\
$\begin{array}{l}\text { Married } \\
\begin{array}{l}\text { Never } \\
\text { married }\end{array}\end{array}$ & 543 & 0 & 64 & 8.2 & 11.7 & 2.8 & 21.2 & 29.5 \\
\hline
\end{tabular}

\subsection{Test of the hypotheses}

First the models for male respondents will be discussed, followed by a discussion of the models for women.

The first model on men, presented in Table 5, is the null model (model 0). This model indicates how much variation in occupational status is found between individuals and how much within individual's careers, i.e., between the different measurements of occupational status. There is more variation in occupational status between men than within men's careers: $82 \%(191.87 /(191.87+41.94))$ of the variance in occupational status is between men.

Model 1 includes age, age squared, as well as year divided by 10 . Hypotheses 1 expects the occupational status of men to increase with experience and to level off towards the end of the working life. However, in this first model the effect of age is positive, but not significant. Only the squared age term has a significant effect: occupational status declines with age at an increasing pace. The estimated top of the 
occupational career of men is reached at age $31[(0.51 / 0.38) * 10+15] .{ }^{5}$ In the second model and all following models, both age and age squared significantly influence occupational status, indicating more support for hypotheses 1 than visible in model 1 . The estimated top of the career remains at about age 30 in all models. Over historical time the overall status of men increases. With every additional 10 years the occupational status of men increases by almost one and a half points (1.50).

In model 2 we test hypothesis 2 on the effect of father's occupational status on the starting point of the career of his son. As expected every additional status point of the father increases the status of the son at his career start by around half a point $(0.60)$.

Our expectation of the effect of marital status on the level of occupational status (hypotheses 5a) is supported (model 4). After getting married the occupational status of men jumps to a level 0.82 points higher than before marriage. Note that in the same model the artificially higher occupational status on the marriage certificate is taken into account. This size of this effect is also around 1 status point.

In models 3 and 5 the interactions of age and year with father's occupational status and marital status are added. Neither the age nor the year interactions with father's status (model 3) yield significant results. The speed at which occupational status grows over a men's life course is not influenced by his father's occupational status, nor does the effect of father's status on the starting level of occupational status of men change over time. Getting married likewise does not change the speed at which occupational status grows over the life course of men (model 5). However, the effect of marrying on the level of occupational status changes over time: With every additional 10 years the positive main effect of getting married (which was 1.86 in 1900) decreases by 0.30 points, which is opposite to hypothesis 7 a.

All models include information on whether the life courses are complete. Men with incomplete register information have on average a 1.4 to 2.6 points higher occupational status. Additional analyses (not shown in the table), however show that the effects of the other variables don't change when taking into account the completeness of the life course information.

The variation between individuals is reduced from 191 (in model 0 and 1) to 137 (in model 2 to 5). The variation within individuals declines from around 42 (model 0 ) to 35 (model 2 to 5). Model 4 performs best with regard to model fit as it is significantly better than model 3 (critical value of 36.7, 2 degrees of freedom). The difference in model fit between model 4 and 5 is not significant.

\footnotetext{
${ }^{5}$ The peak of status in occupational careers is defined as the age at which the slope of the curve is zero. This is calculated as follows: $(0.51 / 0.38)^{*} 10+15$, in which 0.51 is the main effect of age divided by $10,0.38$ is the effect of age divided by 10 multiplied by 2,15 is added because the careers start at the age of 15 .
} 
Schulz \& Maas: Studying historical occupational careers with multilevel growth models

Table 5: Multilevel analyses of the occupational status of men (coefficients and levels of significance) $(N=1407)$

\begin{tabular}{|c|c|c|c|c|c|c|}
\hline & Model 0 & Model 1 & Model 2 & Model 3 & Model 4 & Model 5 \\
\hline Intercept & $47.61^{\star *}$ & $41.64^{\star *}$ & $13.85^{\star *}$ & $11.75^{\star *}$ & $11.11^{\star *}$ & $10.84^{\star *}$ \\
\hline Age/10 & & 0.51 & $1.44^{*}$ & $1.44^{*}$ & $1.06^{*}$ & 0.90 \\
\hline$(\mathrm{Age} / 10)^{2}$ & & $-0.19^{\star *}$ & $-0.43^{* *}$ & $-0.43^{\star *}$ & $-0.36^{* *}$ & $-0.33^{\star \star}$ \\
\hline Year/10 & & $1.50^{*}$ & $1.50^{\star *}$ & $1.50^{\star \star}$ & $1.52^{\star *}$ & $1.67^{\star *}$ \\
\hline Father's occupational status & & & $0.60^{* *}$ & $0.65^{* *}$ & $0.65^{* *}$ & $0.65^{\star *}$ \\
\hline After marriage & & & & & $0.82^{*}$ & $1.86^{*}$ \\
\hline Incomplete & & $2.60^{*}$ & 1.31 & $1.40^{*}$ & $1.40^{*}$ & $1.42^{*}$ \\
\hline Marriage certificate & & & & & $1.26^{* *}$ & $1.06^{*}$ \\
\hline \multicolumn{7}{|l|}{ Speed of growth } \\
\hline $\begin{array}{l}\text { Age } / 10^{*} \text { Father's } \\
\text { occupational status }\end{array}$ & & & & -0.03 & -0.03 & -0.02 \\
\hline Age $/ 10^{*}$ Married & & & & & & -0.08 \\
\hline \multicolumn{7}{|l|}{ Over time } \\
\hline $\begin{array}{l}\text { Year/10*Father's } \\
\text { occupational status }\end{array}$ & & & & -0.02 & 0.02 & 0.02 \\
\hline Year/10*Married & & & & & & $-0.30^{*}$ \\
\hline Variation between individuals & 191.87 & 191.13 & 136.91 & 136.70 & 137.68 & 137.60 \\
\hline Variation within individuals & 41.94 & 39.76 & 35.83 & 35.84 & 35.46 & 35.46 \\
\hline $\begin{array}{l}\text { Model fit (degrees of } \\
\text { freedom) }\end{array}$ & 40267.02 & $234.59(4)$ & $3020.72(1)$ & $12.84(2)$ & $36.7(2)$ & $0.66(2)$ \\
\hline
\end{tabular}

${ }^{* *} p<0.01 ;{ }^{*} p<0.05$

Note: Experience starts to count at age 15, year starts to count at 1865, and in the interactions year is centered around 1900.

The same sequence of models was estimated for women (see Table 6). The first model is the null model (model 0). Similar to men, there is more variation in occupational status between women than within female careers: $73 \%$ of the variance in occupational status is between women. This means that relatively, there is about $10 \%$ more variance within female careers than within male careers, which is surprising in the light of their shorter duration.

For women the expected increase of occupational status with increasing experience and the leveling off at later ages is found (see model 1 ). With every 10 years of age 
there is an increase in occupational status by 6 points. Over time the increase is reduced as indicated by the squared age term. The top of the occupational career of the women is reached at the very end of their career around age $71[6.35 / 0.31 * 10+15]$. The occupational status of women did not change significantly over historical time.

In model 2 father's occupational status is added. With every additional status point of the father the occupational status of the daughter at the start of her career increases by around half a point $(0.44)$.

Model 3 additionally includes interactions of age and year with father's occupational status. Against our expectations, the higher the occupational status of the father, the slower the growth of status over the life course of their daughters. The effect is -0.16 . This means that for each status point of the father the growth in status of the daughter over 10 years is 0.16 smaller. Daughters of higher status fathers started their career on a higher level ( 0.72 points higher for each status point of the father). According to the model, after 44 years this head start has disappeared $\left[0.72 / 0.16^{*} 10=45\right]$.

Also contrary to our expectations with historical time the effect of father's status on the starting level of the daughter's occupational career increases by 0.13 per ten years. Since the variable year was centered around 1900, the main effect of father's occupational status (0.72) applies to the year 1900.

Model 4 includes marital status. Contrary to our expectations women who are married have an occupational status that is 2.65 points higher than that of women who are not (yet) married. The age interaction with marital status (model 5) did not yield significant results. The effect of marrying on occupational status changes over historical time. With every additional 10 years the positive main effect of being married (which was 7.26 in 1900) reduces by 1.33 points.

All models include the information whether the life courses are complete. There is no significant difference in occupational status between women with complete and incomplete information. Neither is there a significant effect of the second control variable which indicates that the occupational information stems from the marriage certificate.

Model 4 performs best with regard to model fit. It performs significantly better than model 3. As with the models for male respondents the difference between model 4 and 5 is not significant. The unexplained variation between individuals reduces from almost 300 in model 0 gradually to around 195 in models 2 to 5 . The variation within individuals reduces from 106 in the null model to 88 in models 2 to 5 . 
Schulz \& Maas: Studying historical occupational careers with multilevel growth models

Table 6: Multilevel analyses of the occupational status of women (coefficients and levels of significance) $(\mathrm{N}=\mathbf{8 2 4})$

\begin{tabular}{|c|c|c|c|c|c|c|}
\hline & Model 0 & Model 1 & Model 2 & Model 3 & Model 4 & Model 5 \\
\hline Intercept & $23.50^{\star *}$ & $15.04^{\star *}$ & $-4.43^{*}$ & $-17.10^{\star \star}$ & $-16.96^{\star *}$ & $-17.47^{* *}$ \\
\hline Age/10 & & $6.35^{\star \star}$ & $6.70^{\star *}$ & $6.50^{\star \star}$ & $5.62^{\star *}$ & $5.22^{* *}$ \\
\hline$(\mathrm{Age} / 10)^{2}$ & & $-0.56^{\star *}$ & $-0.60^{* *}$ & $-0.59^{\star *}$ & $-0.46^{*}$ & $-0.37^{*}$ \\
\hline Year/10 & & 1.12 & 0.72 & 0.87 & 0.85 & 1.00 \\
\hline Father's occupational status & & & $0.44^{\star *}$ & $0.72^{\star \star}$ & $0.72^{* *}$ & $0.72^{* *}$ \\
\hline After marriage & & & & & $2.65^{*}$ & $7.26^{*}$ \\
\hline Incomplete & & -1.17 & -1.18 & 1.26 & -1.28 & -1.26 \\
\hline Marriage certificate & & & & & 1.68 & 0.67 \\
\hline \multicolumn{7}{|l|}{ Speed of growth } \\
\hline $\begin{array}{l}\text { Age } / 10^{*} \text { Father's occupational } \\
\text { status }\end{array}$ & & & & $-0.16^{*}$ & $-0.15^{*}$ & $-0.16^{*}$ \\
\hline Age/10*Married & & & & & & 0.63 \\
\hline \multicolumn{7}{|l|}{ Over time } \\
\hline $\begin{array}{l}\text { Year/10*Father's } \\
\text { occupational status }\end{array}$ & & & & $0.13^{*}$ & $0.13^{*}$ & $0.13^{*}$ \\
\hline Year/10*Married & & & & & & $-1.33^{*}$ \\
\hline Variation between individuals & 299.87 & 231.06 & 199.33 & 198.61 & 196.47 & 195.96 \\
\hline Variation within individuals & 106.32 & 90.11 & 88.62 & 88.31 & 88.05 & 87.96 \\
\hline $\begin{array}{l}\text { Model fit (degrees of } \\
\text { freedom) }\end{array}$ & 19912.40 & $471.46(4)$ & $395.67(2)$ & $2.88(2)$ & $21.37(2)$ & $6.48(2)$ \\
\hline
\end{tabular}

${ }^{* *} p<0.01 ;{ }^{*} p<0.05$

Note: Experience starts to count at age 15, year starts to count at 1865, and in the interactions year is centered around 1900. 


\section{Discussion and conclusion}

In this paper we proposed a method to study career success with historical occupational data. Common issues of historical data, i.e., the unknown exact timing of changes in the occupational status, make standard methods to study careers, such as event history modeling, less applicable. At the same time, historical data often comprise significant time spans of an individual's life as well as historical time that makes them well suited for the study of careers.

We proposed to use multilevel growth modeling. The multilevel growth models overcome the problems of historical data and take advantage of their richness. The basic assumption of the proposed models is that occupational status changes ('grows') over the life course. Careers are assumed to start at a higher or lower level depending on the effects of time constant characteristics (e.g., father's occupational status) or to jump to a higher level when a change in a time varying characteristic occurs (e.g., marital status). Moreover, the models enable studying whether the growth in occupational status increases its speed due to time constant or time varying characteristics. In this way, the models nicely correspond to common sense ideas about career success, i.e., successful careers are careers which start at a higher level of occupational status and/or grow in status faster.

We used the Historical Sample of the Netherlands to test some example hypotheses derived from sociological and economic literature on status attainment. The basic idea from human capital theory that occupational status increases over the life course but to a lesser extent at older ages was found for male careers. However, on average, men reached their maximum occupational status already in their thirties, which is unexpectedly early. One possible explanation could be that physical strength was an important determinant of occupational success in the period under study and therefore with decreasing strength career success would decrease likewise. Men whose father had a higher occupational status - our example of a time constant predictor - started their occupational career on a higher level. Marrying - a time varying predictor - let their occupational status jump to a higher level. No indication was found that the speed of growth of occupational status increases with having a higher status father or after getting married. Against our expectations, the effects of father's occupational status did not change over historical time. However, we found that for men the positive effect of being married decreased over time.

Female careers showed the expected pattern of increasing occupational status over the life course but to a lesser extent at older ages. According to the model, a decline in status only happened at very old ages. Daughters from high status fathers started their career in occupations with higher occupational status. This was increasingly the case over historical time. However, the careers of these women developed at a slower speed 
than those of daughters from lower status fathers. Also against our expectations we found a positive effect of being married on women's occupational status. However, this effect is decreasing over historical time.

Two assumptions of the growth models seem problematic when using them for the analysis of historical occupational careers. First, the models assume a regular change of status between two time points at which occupational status is measured. In fact though, we know that people's occupational status changes more abruptly (compare figure 6). However, we think that this is a minor problem. The inclusion of time varying characteristics in the models can take care of jumps in occupational status. Furthermore, models always to some extent summarize complex reality.

The second problem is more severe. Our approach produces counterintuitive results for female careers. For example, whereas we expected women's careers to become less successful after marriage, we found that marriage raises women's occupational status. The cause of these counterintuitive results lays in the assumption of growth models that during the periods that women are not observed they behave in the same way as those women, with similar characteristics, who are observed. In reality, though, many women were not observed because they dropped out of the labor market at or after marriage. Women who remained active in the official labor market were a selective group both on measured and unmeasured characteristics. In the case of the Netherlands around 1900, it seems to have been the case that especially women with high status positions worked in the official labor market after marriage. As a result the models suggest that getting married increases occupational status. Based on these results we conclude that the multilevel growth models as presented here are more suitable for explaining male careers than female careers.

Nevertheless, we are convinced that multilevel growth models can also be used to study female careers. First, almost all women had an occupation until their marriage. One could thus focus on women before they get married and study for instance the influence of social background on premarital occupational careers of a general female population. Second, most women who never got married stayed in the labor market. One could select those women and study their careers. In this way one would study a selective group, but for this group, the model assumptions would be met.

All in all, we conclude that multilevel growth models are a good instrument to analyze historical occupational careers when the assumption is met that individuals stay on the labor market in periods that they are not observed. A great advantage of the models is that they can be extended in many ways. One example is the addition of a family level, to study the similarity and differences of careers of family members. It should also be possible, although less obvious, to apply the models to ordinal class schemes. Finally the models allow including a regional level, in order to take into account the influence of the regional context on career success. 


\section{References}

Becker, G.S. (1975). Human Capital. New York and London: Columbia University Press.

Blau, P.M. and Duncan, O.D. (1967). The American occupational structure. New York: Wiley.

Bottero, W. (2005). Stratification. Social Division and Inequality. London: Routledge. doi:10.4324/9780203339367.

Erikson, R. and Goldthorpe, J.R. (1992). The Constant Flux: A Study of Class Mobility in Industrial Societies. Oxford: University of Oxford.

Ganzeboom, H.B.G., Luijkx, R., and Treiman, D.J. (1989). Intergenerational class mobility in comparative perspective. Research in Social Stratification and Mobility 8: 3-84.

Ganzeboom, H.B.G., Treiman, D.J., and Ultee, W.C. (1991). Comparative Intergenerational Stratification Research: Three Generations and Beyond. Annual Review of Sociology 17: 277-302. doi:10.1146/ annurev.so.17.080191.001425.

Goldin, C. (1994). Understanding the Gender Gap: An Economic History of American Women. In: Burston, P. (ed.). Equal Employment Opportunity: Labor Market Discrimination and Public Policy. New York: Aldine de Gruyter: 17-26.

Goodman, L.A. (1979). Simple models for the analysis of association in crossclassifications having ordered categories. Journal of the American Statistical Association 74(367): 537-552. doi:10.2307/2286971.

Historical Sample of the Netherlands (HSN) (2008). Data Set Life Courses Release 2008_01. http://www.iisg.nl/ hssn/.

Horrell, S. and Humphries, J. (1995). Women's Labour Force Participation and the Transition to the Male-Breadwinner Family, 1790-1865. The Economic History Review 48(1): 89-117. doi:10.1111/j.1468-0289.1995.tb01410.x.

Hox, J. (2002). Multilevel analysis: Techniques and Applications. New Jersey: Lawrence Erlbaum.

International Standard Classification of Occupations (ISCO) (1969). Revised edition 1968. Geneva: International Labour Office. 
Kaelble, H. (1985). Social Mobility in the 19th and 20th Centuries. Europe and America in Comparative Perspective. Leamington Spa: Berg Publishers.

Kalmijn, M. and Luijkx, R. (2005). Has the reciprocal relationship between employment and marriage changed for men? An analysis of the life histories of men born in the Netherlands between 1930 and 1970. Population Studies. 59(2): 211-231. doi:10.1080/00324720500099587.

Kerckhoff, A.C. (1995). Institutional Arrangements and Stratification Processes in Industrial Societies. Annual Review of Sociology 21(1): 323-347. doi:10.1146/annurev.so.21.080195.001543.

Kerr, C., Dunlop, J.T., Harbison, F.H., and Myers, C.A. (1960). Industrialism and Industrial Man. Cambridge, Mass.: Harvard University Press.

Korenman, S. and Neumark, D. (1991). Does Marriage Really Make Men More Productive?. The Journal of Human Resources 26(2): 282-307. doi:10.2307/145924.

Lambert, P.S., Zijdeman, R.L., Maas, I., Prandy, K., and van Leeuwen, M.H.D. (2008). HIS-CAM - Presentation and evaluation of an historical occupational stratificaton scale based upon the analysis of social interaction. Paper presented at the European Social Science History conference, Lisbon, 26 February - 1 March 2008 (http://www.camsis.stir.ac.uk/hiscam/ last accessed August 23 2010).

Lewis, J. (2001). The Decline of the Male Breadwinner Model: Implications for Work and Care. Social Politics 8(2): 152-169.

Leydesdorff, S. (1977). Verborgen arbeid, vergeten arbeid. Een verkenning in degeschiedenis van de vrouwenarbeid rond negentien-honderd. Amsterdam: Gorcum Assen.

Maas, I. and van Leeuwen, M.H.D. (2002). Industrialization and intergenerational mobility in Sweden. Acta Sociologica 45:179-194. doi:10.1080/00016 990260257175.

Maas, I. and van Leeuwen, M.H.D. (2004). Occupational Careers of the Total Male Labor Force during Industrialization: The Example of Nineteenth-century Sweden. In: Mitch, D., Brown, J., and van Leeuwen, M.H.D. (eds.). Origins of the modern career. Aldershot: Ashgate: 227-258. 
Maas, I. (2004). The use of Event-History-Analysis in Career Research. In: Mitch, D., Brown, J., and van Leeuwen, M.H.D. (eds.). Origins of the modern career. Aldershot: Ashgate: 56-79.

Mandemakers, K. (2004). De Historische Steekproef Nederlandse bevolking (HSN) en het project Life Courses in Context. Bevolking En Gezin 33: 91-114.

Marsh, H.W. (2007). Do University Teachers Become More Effective With Experience? A Multilevel Growth Model of Students' Evaluations of Teaching Over 13 Years. Journal of Educational Psychology 99(4): 775-790. doi:10.1037/0022-0663.99.4.775.

Mincer, J. and Polachek, S. (1974). Family Investments in Human Capital: Earnings of Women. The Journal of Political Economy 82 (2, Part 2: Marriage, Family Human Capital, and Fertility):76-108.

Mitch, D., Brown, J., and Van Leeuwen, M.H.D. (eds.) (2004). Origins of the modern career. Aldershot: Ashgate.

Pavan, R. (2006). Career Choice and Wage Growth. University of Rochester.

Pfau-Effinger, B. (2004). Socio-historical paths of the male breadwinner model - an explanation of cross-national differences. British Journal of Sociology 55(3): 377-399. doi:10.1111/j.1468-4446.2004.00025.x.

Prandy, K. (2000). Class, the Stratification Order and Party Identification. British Journal of Political Science 30(2): 237-258. doi:10.1017/S0007123400000119.

Prandy, K. and Lambert, P.S. (2003). Marriage, Social Distance and the Social Space: An Alternative Derivation and Validation of the Cambridge Scale. Sociology 37(3): 397-411. doi:10.1177/00380385030373001.

Raudenbush, S.W. and Bryk, A.S. (2002). Hierarchical linear models: applications and data analysis methods. London: Sage Publications.

Reher, D.S. and Schofield, R. (1993). Old and New Methods in Historical Demography. Oxford: Clarendon Press.

Sagiv, A. (1979). General Growth Model for Evaluation of an Individual's Progress in Learning. Journal of Educational Psychology 71(6): 866-881. doi:10.1037/0022-0663.71.6.866.

Shavit, Y. and Blossfeld, H.-P. (eds.) (1993). Persistent inequality: Changing educational attainment in thirteen countries. Boulder: Westview Press. 
Thurow, L.C. (1975). Generating Inequality: Mechanisms of Distribution in the U.S. Economy. New York: Basic Books.

Treiman, D.J. (1970). Industrialization and Social Stratification. In: Laumann, E.O. (ed.). Social Stratification: Research and Theory for the 1970s. New York: Bobbs-Merrill Company: 207-234.

van Leeuwen, M.H.D. and Maas, I. (2007). Economische specialisering en veranderende sociale verhoudingen in de $19 \mathrm{e}$ en $20 \mathrm{e}$ eeuw. Een studie op basis van de Nederlandse volkstellingen en huwelijksakten. In: Boonstra, O.W.A., Doorn, P.K., van Horik, M.P.M., van Maarseveen, J.G.S.J., and Oudhof, J. (eds.). Twee eeuwen Nederland geteld. Onderzoek met de digitale Volks-, Beroeps- en Woningtellingen 1795-2001. Statistics Netherlands: 181-205.

van Leeuwen, M.H.D., Maas, I., and Miles, A. (2004). Creating a Historical International Standard Classification of Occupations: An Exercise in Multinational Interdisciplinary Cooperation. Historical Methods. A Journal of Quantitative and Interdisciplinary History 37(4): 186-197. doi:10.3200/HMTS.37.4.186-197.

van Poppel, F., van Dalen, H.P., and Walhout, E. (2009). Diffusion of a social norm: tracing the emergence of the housewife in the Netherlands, 1812-1922. The Economic History Review 62(1): 99-127. doi:10.1111/j.14680289.2008.00433.x.

van Zanden, J.L. and van Riel, A. (2000). Nederland 1780-1914: staat, instituties en economische ontwikkeling. Amsterdam: Uitgeverij Balans.

Zijdeman, R.L. (2008). Intergenerational transfer of occupational status in nineteenth century Zeeland, The Netherlands: A test of the influence of industrialisation, mass communication and urbanisation in 117 municipalities. International Journal of Sociology and Social Policy 28(5/6): 204-216. doi:10.1108/01443330810881259. 